\title{
FOCUS
}

\section{FOOTBALL, NATION, AND WOMEN IN ARGENTINA: REDEFINING THE FIELD OF POWER}

\author{
FUTEBOL, NAÇÃO E MULHERES NA ARGENTINA: REDEFININDO O \\ CAMPO DO PODER C P
}

FÚTBOL, NACIÓN Y MUJERES EN ARGENTINA: REDEFINIENDO EL CAMPO DEL PODER C्户

doi) https://doi.org/10.22456/1982-8918.109761

\begin{abstract}
Derónica Moreira* <veromoreira175@gmail.com>
Gabriela Garton*<gabygarton@gmail.com>
\end{abstract}

\begin{abstract}
*Universidad de Buenos Aires. Instituto de Investigaciones Gino Germani. Buenos Aires, Argentina.
\end{abstract}

\begin{abstract}
Who has featured in the stories about the nation? Who has been able to narrate the histories of sport, football, and the fatherland? What institutions have been central to this construction? But where are the women? Which arguments have been used to exclude them from the field of play? These and other questions guide this article which aims to reflect on sport as a gendered and gendering practice, as a space of production of inequalities as well as opportunities. This article builds its arguments upon data drawn from the analysis of interviews and informal discussions the authors have carried out with football players from Argentina's women's national team and the official Argentine Football Association's (AFA) Women's League as well as articles from the online edition of the daily sport publication Ole during the FIFA 2019 Women's World Cup in France.
\end{abstract}

Keywords: Football. Nation. Women.
Received: 10 Dec. 2020 Accepted: 10 Jan. 2021 Published: 05 Feb. 2021

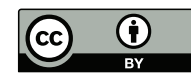

This is an article published in open access under the Creative Commons Attribution 4.0 (CC BY 4.0)

eISSN: $1982-8918$ 


\section{INTRODUCTION}

This work addresses the issue of national representation in a sport as popular as football is in Argentina. Traditionally, who has featured in the stories about the nation? Who has been able to narrate the histories of sport, football, and the fatherland? What institutions have been central to this construction? But where are the women? Which arguments have been used to exclude them from the field of play? These and other questions guide this article which aims to reflect on sport as a gendered and gendering practice, as a space of production of inequalities as well as opportunities.

In Argentina -and most of the world-, since the first evidence of women playing football in the early $20^{\text {th }}$ century, the bodies of those who have chosen to practice this sport have experienced stigmatization, silencing, and disciplining. One hundred years later, we have seen a series of advances in the conditions for contemporary women's football in regards to material recognition -the professionalization of the sport- and symbolic recognition -increased visibility in the media and advertising. Nevertheless, these decisions have their own limitations, and structural inequalities persist. Given the attention that the feminist movement has received in its demands for equal rights and opportunities for women and LGBTQ+ persons, and considering some of the changes which have been made in such an unequal field as sport, we ask whether it is possible to consider women's football as a reference to construct significations of a nation. What representations are considered legitimate to think about Argentineness in the field of sport? Currently, which operations are the most common in the media regarding female athletes?

This article builds its arguments upon data drawn from the analysis of interviews and informal discussions the authors have carried out with football players from Argentina's women's national team and the official Argentine Football Association's (AFA) Women's League as well as articles from the online edition of the daily sport publication Olé during the FIFA 2019 Women's World Cup in France.

\section{INEQUALITIES}

We have heard firsthand testimonies from athletes of different sporting disciplines about a diverse range of discrimination they have faced in their practice. The feminist collective Argentine Athletes (Deportistas Argentinas) brings sportswomen together who demand a "more just and equitable" sport. Among their activities of conscientization and activism, they also speak out against experiences of harassment, abuse and other kinds of violence. One member of the collective, Carolina Luján, a Woman Grandmaster and an International Master, and her teammates openly criticized the Argentine Chess Federation for its lack of support during the Olympiad of 2018 in Batumi, Georgi. The female players were not consulted in the appointment of their coach; the official uniform was different for the men and women, while the men had six sponsors, the women had only two; the administrators only arranged for the men to receive stipends ${ }^{1}$ while the women had to find their own support; finally, the female players were not invited to a lunch organized by one of the team sponsors.

\footnotetext{
1 A payment to cover the costs incurred by attending practices and/or competitions.
} 
Paula Reggiardo, another member of the same collective who is a former basketball player and current coach, manifested her own indignation on social media when she read the tribute prepared by the Argentine Basketball Confederation for "National Coach's Day": a flyer with images of various male coaches but no women, an act which silenced the careers and even the existence of women in the profession.

These situations present a series of problems that occur throughout the field of sports. Where does prestige and recognition circulate? Who is esteemed and valued? Who is able to narrate sporting experiences and careers? In 2017, through an open letter to AFA's Commission on Women's Football, the players of the women's national team requested the fulfillment of the payment of their stipend, better organization of future sporting competitions, adequate locker rooms for the number of players in the squad, and the opportunity to train on the natural grass fields of AFA's grounds. The appeal for better planning of sporting trips emerged from the poor organization of a friendly against Uruguay in Montevideo where the players traveled from Buenos Aires at 4 a.m. to play the same afternoon. The team did not have the chance to rest adequately prior to the competition -players tried to sleep on the bus and no hotel was provided- and returned to Argentina after the match ended, arriving back in Buenos Aires late into the night.

Following the lack of response to their letter, the players went on strike. Though this did not lead to a clear resolution -in late February 2018 they returned to trainings following the call-up in preparation for the Copa America held in Chile in April of the same year-, the protest marked a turning point in their relationship with AFA's authorities and the media. They added to the demands listed in the letter, asking for a better planning of training sessions around players' work schedules as well as more economic and institutional support while exposing the authorities' mistreatment and abuse of power. These are among the most common demands of athletes from other sporting disciplines. With only two weeks of training and without prior international friendlies, Argentina achieved a third-place finish in the Copa America, which gave the team the opportunity to compete in a play-off match to qualify for the 2019 FIFA World Cup. The third-place finish was celebrated as a major accomplishment because of the conditions described above.

Sport, like so many other areas of society, is a practice heavily influenced by gender relations, which have not been reciprocal in terms of equality nor have women been offered the same opportunities to form themselves autonomously and freely in this space (MONCÓ, 2011). Since its beginnings, sport has been androcentric: it functioned to form strong and healthy citizens, capable of conducting activities in the public space, while educating women about caretaking and reproductive duties. Although sport has lost some of its exclusiveness with the entry of the first women into competitions, especially those who challenged the gender order by practicing "masculine" disciplines, throughout time its hierarchical structure still persists. Female athletes continue to be marginalized and judged according to the "legitimate" male standard. Nevertheless, the combination of the demands made by elite female athletes - as well as girls, young women, and adults of other sporting spaces - with the ideals put forth by the national women's movement has provoked the modification 
of the boundaries and rules of this unequal arena. It is not a coincidence that football has been the field where the tension has originated: not only is it our national sport but also a school of masculinities.

\section{THE PROBLEM OF HISTORY}

The lack of sources, that is, the silence or scarcity of written records, should not bring us to the conclusion that there are no women practicing "men's sports" (GOELLNER; JAEGER; FIGUEIRA, 2011). Various studies offer valuable data and interpretations regarding women's football in the first decades of the $20^{\text {th }}$ century. At Club Boca Juniors' stadium in the city of Buenos Aires on October $12^{\text {th }}, 1923$, a match was played between two female teams, Argentinas and Cosmopolitas (ELSEY; NADEL, 2019; PUJOL, 2019)2. The oldest record of a women's football match in Argentina was an encounter between two teams from Club Fémina on October $5^{\text {th }}, 1913$ on the grounds of the Rural Society in the city of Rosario, Santa Fe (OSSOLA, 2020).

In a different sporting space, the historian Patricia Anderson (2015) narrates how in the 1920s many Argentine women adopted a physically active lifestyle that challenged masculine hegemony. The criteria used (between 1880 and the first World War) to form strong, well-trained, and healthy bodies via physical activity also functioned to justify the incorporation of women but with different motives such as increasing fertility and having healthier children. Physical activity was considered to improve women's maternal qualities and caregiving capacity. Anderson (2015) asserts that although this reinforced the gender order, these women also disputed the mandates of that era because their practice also symbolically referred to the right to enjoy, control, and use their own bodies. ${ }^{3}$ On the other hand, she explains that the "experts" - media analysis, pedagogues, educators, and physicians- warned against the inappropriate and excessive practice of physical activity by women which could make them masculine. "Machona" ("butch") was the term used to refer to women who were seen as masculine and overly vigorous; they represented a deviance from femininity and subverted what was considered gender-appropriate behavior.

Football was one of those sports that, if practiced by women, drew the attention and skepticism of the "experts". In an article titled "Why should women not play football?" written by Andy Ducat, an English footballer, in the sport magazine El Gráfico published on January $15^{\text {th }}, 1921$, the author maintains that women who play this sport for "tough men" could become muscular, stop being women, and become a "marimacho" ("tomboy"). In the same vein, Argentine writer Bernardo Canal Feijóo dedicated a poem in his 1924 collection Penultimate poem of football called "Women's Football" which revealed the sanction that existed around the sport because its association with lesbianism and unbridled sexuality. "Machona" and "marimacho"

2 Both Brenda Elsey and Ayelen Pujol are participants in the Research Network on Women's Football coordinated by David Wood, Silvana Goellner, and Veronica Moreira and financed by the United Kingdom Arts and Humanities Research Council.

3 These women were typically from the middle and higher sectors of society in Buenos Aires. The sports they practiced included tennis, golf, and swimming while they would gather for social events at mixed-gender or femaleonly clubs such as the Female Cyclist Club in Villa Devoto (ANDERSON, 2015).

4 Thank you to David Wood for drawing our attention to these texts in his presentation at the Gino Germani Research Institute of the Department of Social Studies of the University of Buenos Aires in May 2016. 
were the terms utilized to belittle female footballers who, with their play, challenged the gender order, heteronormativity, and the essentialized role of women as mothers and caregivers. ${ }^{5}$

Half a century after the first women entered the sport, the Argentine players who traveled to Mexico to play the 1971 unofficial women's football world championship describe the sanctions they suffered for enjoying a sport which had not been considered for them. These players, who carried the shame and stigma of being different from the socially accepted model of femininity, later transformed the same stigma into self-love, pride, and a badge of honor. Today, the Pioneers (Pioneras), as they are now known in Argentina, are recognized by the media, football authorities, political sector, academia, and feminist collectives as representatives of an act of resistance. The squad travelled without football boots, a team doctor, or even a coach to participate in the competition, which reunited teams of different nationalities. In spite of these obstacles, the team managed to defeat England 4-1 in the famous Azteca Stadium. Currently, some of the members of the team have helped compile the history of women's football from previous decades, from 1950 through the early 2000s.

The foundations, histories, legends, dates, and names in women's football are essential elements in the field of dispute to convert silence into recognition. Gabriela Garton and Nemesia Hijós (2018) identify, among other operations, the erasure of women's experiences. When FIFA presented itself as responsible for the growth of women's football around the globe, these authors assert that "this 'legitimization' has attempted to simultaneously hide a history which goes beyond 1991. As in Argentina, prior to the officialization of women's football, in many other countries there were already women playing and competing without the support or recognition of their national federation"6 $(2018$, p. 30). The lack of information and promotion by the national federation on women playing the country's most popular sport in earlier decades - like the history of the Pioneers - has been an operation utilized constantly. Even more than twenty years after the inauguration of the Argentine women's league in 1991, the silencing of the women aiming to expand their rights continues to be a strategy utilized by the structures of power. On March $16^{\text {th }}, 2019$, the president of AFA announced the professionalization of women's football, but after the same announcement, when faced with questions from journalists during the press conference, he dismissed the prior struggle of the national team and of local players from different divisions and leagues across the country to gain recognition and support.

Thus, we can identify two operations that have influenced how history is told: silencing and stigmatization. Currently, in light of the advancement of athletes' demands and those of feminist movements for equity in football, some changes have been made in regards to material recognition - professionalization - and symbolic recognition coverage in media and marketing campaigns. In this new context, the usage of the term "machona" to describe female footballers has been almost abandoned but has

5 The preoccupation around lesbianism and the "machona" image in football persisted until recent years, though in the last period this was more for economic rather than moral reasons. The image of butch and/or lesbian players was "difficult to market" for the same local and international sporting institutions which had spent the last century constructing these labels to keep women out of football (WILLIAMS, 2007; SCHULTZ, 2014; GARTON, 2019).

6 Translated from original Spanish by the first author of this text. 
been replaced by other kinds of stigmas. "Quilombera" or "troublemaker" - though the term originally was used as slang to refer to prostitutes - is the name applied to belittle the athlete who asks questions and makes demands of the authorities for better conditions in the sport, whether directed toward administrators or coaches, on social media, and/or in interviews with journalists. "Desagradecida" or "ungrateful" is another negative adjective used to describe the players who, supposedly, do not acknowledge the changes in football and continue demanding improvements.

The history of women's football in Argentina has become a topic of interest both for specialists of the social sciences and humanities and for feminist groups, not only because of its potential to narrate the unequal relations that have oppressed these women or the ways they have been indoctrinated and disciplined but also because it serves to identify experiences of resistance. Knowing and narrating "histories" are ways to insert female footballers as their own references for current and future generations as well as to create their own origin myths and a memory that disputes the official and existing story.

\section{ARGENTINENESS IN DISPUTE}

Throughout most of the $20^{\text {th }}$ century, football was used in the construction of a national identity and of hegemonic masculinities. This process came about through a collaboration among various actors, including, and not in a secondary role, the media and the State. The first group, while constructing national narratives based on the accomplishments and accolades of Argentine male players and teams -the invention of the "criollo" style or play, the idealization of the "potrero" or "sandlot", and the glorification of the "pibe" or "kid"- satirized, criticized, or mostly ignored women's football, though occasionally some favorable texts or images were published (ELSEY; NADEL, 2019; GARTON, 2019). In regards to the second group, the State, public education was key. According to Beatriz Sarlo (1998) the Argentine publicschool system functioned as a kind of "cultural machine" where citizenship was constructed. The State used schools, more or less effectively, in the development of a national pedagogical discourse with the goal of building a national identity and thus incorporating a vast number of immigrants into civil society. Physical education (PE) also played a fundamental role in schools in the education of sexed bodies, encouraging girls to participate in activities that reinforced the ideals of femininity such as gymnastics and dance while urging boys to participate in practices associated with hegemonic masculinity (SCHARAGRODSKY, 2006).

Pablo Alabarces (2002) analyzes how the media organized a narrative intersecting patriotism with sport. The official myth put into play by the dominant classes in the process of constructing a national identity was founded upon the image of the domesticated "gaucho" or Argentine cowboy. Around 1912, the gaucho was consecrated as an epic symbol of Argentine nationalism due in large part to the impulse provided by prestigious intellectuals with national recognition. Along with the

7 According to the Argentine football imaginary, a "pibe" is a young boy who grows up playing football in "potreros" which are empty, unpaved lots in the city converted by the young men of the neighborhood into improvised fields (ARCHETTI, 2008). Naturally, the idea of "potrero" is the antonym of the official fields of the British schools where teachers organized and controlled the matches, teaching the rules and modes of play to their obedient students. 
gaucho, other "popular and real heores" appeared: athletes (ALABARCES, 2002). The media played a pivotal role in the development of this sporting national identity based on these heroes who originated primarily from the popular sectors of society. Alabarces suggests that the first Argentine nationalism promoted by the elites was complemented by a sporting nationalism "which by position, because it transforms the space of what can be represented and what is represented, is more democratic since it trusts in the capacity of popular heroes and practices to invest in the significations of the nation" (2002, p. 47). In this way, Alabarces, in reference to Sarlo's metaphor, football began to function as a "cultural machine", a developer of nationalism, in the 1920s alongside the educational and State machine. The nationalist narratives of football coexisted with a high grade of coherence with the State narratives; they were complementary, not contrary, to the official narratives established by the State.

Alabarces (2014) also suggests that football's success as an arena for the debates around national identity has to do with its condition as a cultural "free zone". Free zones are areas where identities and new narratives are discussed and reinvented in a more creative way than in serious and classic spaces such as schools, the armed forces, or universities. Eduardo Archetti initially proposed this concept while considering that the development of a national identity can occur on the fringes, in the marginal practices such as sport or dance, which are fertile spaces to generate significant and relevant discourses on the nation. These free zones can be recognized by presence of freedom and the potential for creation.

Nonetheless, national identity in football also carries with it a gender condition. Football is gendered and gendering practice; that is, gender relations affect it from its very constitution and, at the same time, it constantly shapes structural inequalities. Thus, women have not had the same opportunity as men to experience autonomy in this "free zone". The flipside of the consolidation of football as a popular and democratic sport, which offered opportunities to youth from middle and popular sectors and functioned to consider Argentineness, has been a set of operations of restriction, discipline, and control of women's bodies. The social exclusion of women from such a massive collective implied a symbolic exclusion in regards to the impossibility of female athletes becoming protagonists in patriotic narratives. Women were unable to symbolically represent the nation (RIAL, 2013). We find ourselves faced with a masculine narrative of the nation which is produced, reproduced, dominated, and administrated by men.

How do discourses and stories of the nation in football function in global society? Alabarces (2014) considers that mass culture is the central space of contemporary culture, where the majority of the debate agenda -what we can or should discuss at a particular time - is established, and it consecrates the greater or lesser circulation of those narratives. International competitions are central events during which the clash of nations is ritualized. Particularly, narratives of Argentineness are multiplied in advertisements, television programs, graphic and radio spaces, as well as daily life during the Men's World Cup and the Olympic Games. Argentine fans, especially male ones, are represented as unconditional, creative, original, ardent, and passionate. Based on an essentialist production of fixed and unchangeable traits, this is a 
representation which is quickly and easily recognized; it is built upon a story which is the reduction of a much more diverse and complex reality (HALL, 2003). In this way, a range of issues which deserve to be made visible and exposed is simplified according to this reductive approach to the detriment of a diverse range of experiences.

On the other hand, these representations are constructed upon a base that stems from the "aguante" logic that has dominated Argentine football culture during the last forty years. This logic positively values fans who are active, aggressive, courageous, fervent, and faithful; it also legitimizes the elimination -both real and symbolic- of rivals. In this context of disputes among men for a strong masculinity, female fans have been largely excluded from stadiums and mainly included in media narratives from a commercial perspective, particularly since the 1990s and during world cups where they occupy traditional gender roles such as goddesses, mothers, and wives (CONDE; RODRÍGUEZ, 2002).

\section{MARGINALIZED FOOTBALLERS}

Sport, like any other cultural practice, embodies conflict; it is a space of dispute for its legitimate significations (HARGREAVES, 1993). Who has narrated the history of Argentine football? Who has had the word and the authorized position to communicate the official story? Who have been the protagonists and who has been left out of the narratives? What have been the mechanisms and the reasons for this exclusion?

The mass media has played a key role in this dispute for visibility of women's sporting -and fan- practices. According to Anne Travers (2008), the media has a symbiotic relationship with elite sport which consecrates men's sport and marginalizes its female counterpart with disproportionately unequal levels of coverage and investment -through the distribution of income through sponsors and the buying/ selling of broadcasting rights. This creates an economic circuit which is closed off to elite female athletes. The media not only makes men's sport visible but also affords it greater commercial and cultural value by placing it in the spotlight as an available resource for potential sponsors and investors. For the most part, the system is constructed for men -especially for the hegemonic men's sports- while women are not contemplated or are offered a marginal place.

In Argentina, we have data that demonstrates this underrepresentation of female athletes. The Leonas or Lionesses, the nickname of the Argentine National Women's Hockey team, among the best teams in the world in the sport, do not receive the same level of attention as other male sports such as tennis, rugby, and basketball. For example, Galia Moldavsky ${ }^{8}$ identified 46 articles on women's football in the Argentine newspaper La Nación during 2018. Although this surpasses the number from the previous year, the 9428 articles on men's football still reveals the unequal coverage in regards to gender.

The daily publication Olé is the main medium dedicated to sport in Argentina which establishes the agenda for sporting news in other media and the only one with

8 This data was collected in the context of the UBACyT project "Sport, body, and gender" based out of the Gino Germani Research Institute, Department of Social Sciences, University of Buenos Aires. 
a printed version with national circulation and influence in both Buenos Aires and throughout the country. Analysis of this news outlet demonstrates a similar situation. Although the newspaper's structure corresponds to a mostly football-oriented coverage in its various forms - first division, lower divisions, international -, AFA's women's league is hardly documented.

Furthermore, along with the underrepresentation of women's sport, the sexualization of women and female athletes has been a common operation in sport media, especially in Olé. This can be observed in different forms: sport channels choose to produce programs on fitness routines aimed toward improving physical appearance, reinforcing both the conception of women as an object of the male gaze and the idea that they cannot play sports. When we analyzed Olé a number of years ago, we found not only the de-hierarchization and subordination of female athletes - which was extended to female coaches, officials, and journalists - but also the hypersexualization of women in the section called "The Daily Goddess" ("La Diosa del Día”) (ARAOZ ORTíZ; MOREIRA, 2016; ÁLVAREZ LITKE; MOREIRA, 2019). In this case, the images of young, beautiful, and sensual models functioned as a guarantee of masculinity (RIAL, 2013).

\section{ATHLETES REDEFINING THE POWER STRUCTURE}

In a more recent analysis of Olé, carried out during the 2019 FIFA Women's World Cup in France, we found that the newspaper had made some adjustments which had begun following the 2018 Women's Copa America in Chile. We connected these changes mainly with the women's and LGBTQI+ movements which have become massive in the country and have managed to make visible a set of demands around the expansion of rights regarding access to sport and physical activity, the democratization of sport leadership, and the increase of job opportunities for female coaches and specialists in the field of sport.

The boundary around one of the strongest bastions of the patriarchy in Argentina entered into discussion following a series of events which we will summarize here. The first of these was the massive \#NiUnaMenos (\#NotOneWomanLess) protest which began in 2015 and drew attention to women's struggle against gender violence. Under the slogan "Not one woman less, we want each other alive" ("Ni una menos, vivas nos queremos"), the streets of Argentina, throughout all of the provinces, began to display the power of a movement which existed to question a patriarchal model of society which was killing its female citizens. Moreover, it also served to bring the agenda of claims and demands of this collective to the forefront of the public and media stage.

March $8^{\text {th }}$, also known as $8 \mathrm{M}$, commemorating International Women's Day, since 2017 has called for an international women's strike with the primary demand of equal conditions in the workplace. In the case of Argentina, the third strike was unique in that it also included dissident sexualities and non-binary gender identities.

These actions combined with those of the National Campaign for the Right to Legal, Safe, and Free Abortions, with origins harkening back to 2003 and 2004 at the 
national women's conferences, which are held each year in a different city across the country. All of these actions are known as the Green Tide, whose potential was seen in the mass gatherings in the street in the context of the congressional vote on the Law of Voluntary Interruption of Pregnancy in 2018.

At the same time, these acts, which drew attention to the struggles of women and the LGBTIQ+ collective, also had an impact on women's football and its players, many of whom participated and organized activities in the aforementioned events. In this context, national team players and those of the local league felt supported in the demands they made to the authorities of AFA and their clubs in order to improve the material conditions of competition and training.

Since 2019, we have observed specific changes in the media. In regards to Olé, the elimination of the section "The Daily Goddess" in March of the same year was significant as it had been a classic part of the newspaper. On the other hand, another relevant aspect was the coverage of the 2019 FIFA Women's World Cup in France with various articles, especially during the national team's performance in the group stage.

The cover dedicated to Argentina's playmaker Estefanía Banini praised her efforts in the team's debut against Japan and represented a breakthrough in the regimen of visibility of a newspaper that had never given that place to a female athlete -let alone a female footballer. Nevertheless, the customary androcentric mechanisms still appear in these representations including measuring and comparing these athletes with the "legitimate" model, with the most important players of men's football. Banini has frequently been called the "female Lionel Messi" because of her stature, left foot, and style of play.

Another important occurrence was the association between the players and the symbols of the nation. In the articles and images on the group stage matches of the World Cup, we observed phrases with a patriotic meaning which commonly appear in reference to male athletes and footballers. This could be seen most clearly in relation to the last match of the group stage when Argentina faced Scotland. Both teams needed a win in order to progress to the knock-out round from the "group of death". 9 With only 20 minutes left in the match, Scotland held a 3-0 advantage and seemed well-poised to secure the victory, but in the $74^{\text {th }}$ minute, Milagros Menéndez scored a goal that would start the comeback for the Argentines. With only a few minutes until the final whistle, Florencia Bonsegundo, a forward from a small town in the province of Córdoba, would score two goals to manage a 3-3 draw. This match was the first in the history of the Women's World Cup in which a team managed to equalize after falling 3 goals behind. If Argentina had scored a fourth goal, it would have been the first time the country qualified for the knock-out phase. Even though the another goal did not arrive, the media narratives praised Argentina's performance. In particular, Olé highlighted the team's achievements before and after the match: 
The emotion of the anthem. A moving moment at the Parc des Princes: ${ }^{10}$ during the anthem, many of the national team ladies could not hold back tears. 19 June 2019

Singing the anthem with my teammates is the proudest I have ever felt, representing your country from so far away,' concluded Mayorga. ¡Let's go girls! 20 June 2019

[...]this team inspired hope in an entire country until the end with that chance. 20 June 2019

The footballers were represented in the media using the classic formula of overcoming a difficult situation which, in the case of these women, included the lack of recognition as players from a young age and discrimination in its different forms -e.g., exclusion from the league and stigmatization. The formula of this construction was that of the heroine who could overcome obstacles and trials on her way to recognition and to her destiny. It was also common to see some players mentioned as mothers, a characteristic which does not appear when the protagonists are male athletes. It is worth noting that this is a way of naturalizing, once again, women's maternal and caregiving role. These strategies are part of a framing technique known as "ambivalence" which uses contradictory messages in the representation of female athletes which trivialize or minimize their abilities or sporting achievements (CRANMER; BRANN; BOWMAN, 2014). Certain visual methods can be used -for example, a close up during an advertisement of a body part strongly associated with femininity such as breasts or the midriff- or the choice of words and the discussion of non-sporting themes associated with femininity -such as the complementary role of the female athlete as mother, girlfriend, wife, and/or daughter. Cheryl Cooky, Michael Messner, and Michela Musto (2015) identified a connection between the obviously biased coverage of athletes in the mass media and unequal social change, in which women's challenge of hegemonic masculinity in sports remains limited by persistent gender ideologies, structural inequalities, and sex segregation.

The narrative built on goalkeeper Vanina Correa follows is an example of this kind of representation. She had an excellent performance in the second match of the group phase against England and was named player of the match. The narrative constructed around her highlighted two classic topics. On one hand, it praised her overcoming of material conditions and adversity in life to fulfill her dream (to play for the national team and in the world cup -in her case, two world cups-). This is a common operation and has been used to narrate the story of male athletes such as Argentine Braian Toledo who recently passed away but originally emerged from the Evita Games, a national youth sporting competition, to become a world-class javelin thrower. On the other hand, her role as mother is emphasized: "She left her twins behind" to train as a goalkeeper and play in an international tournament. This phrase also has a double meaning. While it recognizes her sacrifice to travel without her children, it also questions her maternal capacity, using the expression "leave behind" in reference to her caregiving responsibilities, something which is not asked of male footballers. Thus, following Rial's (2013) work, for many years women's bodies were labeled as inferior to those of men, incapable of the same feats, while they were

10 Home stadium of Club Paris Saint Germain, one of the wealthiest and currently most competitive clubs in the world, with a capacity of almost 48 thousand people. 
also sanctified under the ideological cloak of maternity. Today, after various decades, maternity continues to be evoked in the narratives dedicated to female athletes (RIAL, 2013).

\section{THE FINAL SCORE}

Modern sport is an arena of conflict, a battlefield where different actors try to maintain or change the rules of play. Even though we can observe these tensions in a dynamic and procedural manner throughout a variety of practices in our society, we choose to study sport because it has carried a condition of gender since its origin. We have heard firsthand testimony from female athletes of their most common and diverse daily experiences in their clubs and spaces of competition and training. We also know the sanctions these women -and those of previous generations- have faced for choosing sports which defy gender norms. For these athletes, it has been common to resist years of silencing and stigmatization of their practices.

At the same time, excluding women from football -as both players and fanshas also meant leaving them out of a massive collective and the opportunity to represent meanings associated with the nation. Nevertheless, the 2019 Women's World Cup, along with the increasingly visible struggles of female footballers for better conditions in regards to both material and symbolic recognition, indicated a potential turning point after a century of invisibility and marginalization. In spite of these apparent advances, such as the increase in representation of the women's national team in the most influential sports publication in Argentina, mechanisms of exclusion and trivialization of female athletes continue to be utilized. They are still not permitted to reach the same levels of stardom as their male counterparts nor to have the same potential of representing the nation. This work thus leaves the question as to whether the current inclusion of female footballers in the media allows us to consider the construction of their own references regarding what is patriotic (can they be national heroines?) and/or whether their inclusion can be attributed to the logic of neoliberalism which commercializes everything it touches.

The intersection of the demands of the feminist movement in search of equal rights and opportunities for women and LGBTQ+ persons and the extremely poor conditions of existence of female footballers has opened the way for a union among different sectors along a same battle front (though not without divisions). In this framework, the search for "histories" which challenge the official history of sport and nation has become an objective which will allow for the boundaries and rules of play of a field in contention to become-even more- disputed. 


\section{REFERENCES}

ALABARCES, Pablo. Fútbol y Patria. El fútbol y las narrativas de la nación argentina. Buenos Aires: Prometeo, 2002.

ALABARCES, Pablo. Héroes, machos y patriotas: el fútbol entre la violencia y los medios. Buenos Aires: Aguilar, 2014.

ÁLVAREZ LITKE, Martín; MOREIRA, Verónica. Un análisis de las representaciones mediáticas y las desigualdades estructurales en el fútbol de mujeres en Argentina. FuLiA/ UFMG, v. 4, n. 1, p. 98-116, 2019

ANDERSON, Patricia. Sporting Women and Machonas: negotiating gender through sports in Argentina, 1900-1946. Women's History Review, v. 24, n. 5, p. 700-720, 2015.

ARAOZ ORTÍZ, Leandro; MOREIRA, Verónica. Prensa deportiva en Argentina. Construcciones identitarias y estilos discursivos del deporte en el diario Olé. Trama de la Comunicación, v. 20, n. 2, p. 111-124, 2016.

ARCHETTI, Eduardo. El potrero y el pibe. Territorio y pertenencia en el imaginario del fútbol argentino. Horizontes Antropológicos, n. 30, p. 259-282, jul./dez. 2008.

CONDE, Mariana; RODRIGUEZ, María Graciela. Mujeres en el fútbol argentino: sobre prácticas y representaciones. Alteridades, v. 12, n. 23, p. 93-106, 2002.

COOKY, Cheryl; MESSNER, Michael; MUSTO, Michela. "It's Dude Time!": A Quarter Century of Excluding Women's Sports in Televised News and Highlight Shows. Communication and Sport, v 3, n. 3, p. 261-287, 2015.

CRANMER, Gregory; BRANN, Maria; BOWMAN, Nicholas. Male Athletes, Female Aesthetics: The Continued Ambivalence Toward Female Athletes in ESPN's The Body Issue. International Journal of Sport Communication, v. 7, n. 2, p. 145-165, 2014.

ELSEY, Brenda; NADEL, Joshua. Futbolera: a history of women and sports in Latin America. Austin: University of Texas, 2019.

GARTON, Gabriela. Guerreras: Fútbol, mujeres y poder. Buenos Aires: Capital Intelectual, 2019.

GARTON, Gabriela; HIJOS, Nemesia. "La deportista moderna": género, clase y consumo en el fútbol, running y hockey argentinos. Antípoda. Revista de Antropología y Arqueología, n. 30, p. 23-42, 2018.

GOELLNER, Silvana; JAEGER, Angelita; FIGUEIRA, Márcia Machado. Invisibilidade não significa: imagens de mulheres em obras referenciais do skate e do fisiculturismo no Brasil. Ex aequo, n. 24, p. 135-148, 2011.

HALL, Stuart. The spectacle of the 'other'. In: HALL, Stuart. Representation: cultural representations and signifying practices. London: SAGE, 2003. p. 223-290.

HARGREAVES, Jennifer. Promesa y problemas en el ocio y los deportes femeninos. In: BROHM et al. Materiales de sociología del deporte. Madrid: La Piqueta, 1993. p. 109-132.

MONCÓ, Beatriz. Antropología del género. Madrid: Síntesis, 2011. 
OSSOLA, Bianca. En 1913 se jugó en Rosario el primer partido de fútbol entre mujeres del que se tiene registro. El Ciudadano, 4 oct. 2020. Disponible en: https://www. elciudadanoweb.com/en-1913-se-jugo-en-rosario-el-primer-partido-de-futbol-entre-mujeresdel-que-se-tiene-registrol. Consultado en: 2 nov. 2020.

PUJOL, Ayelén. ¡Qué jugadora! Un siglo de fútbol femenino en la Argentina. Buenos Aires: Ariel, 2019.

RIAL, Carmen. El invisible (y victorioso) fútbol practicado por mujeres en Brasil. Nueva Sociedad, n. 48, p.114-126, 2013.

SARLO, Beatríz La máquina cultural: Maestras, traductores y vanguardistas. Buenos Aires: Ariel, 1998.

SCHARAGRODSKY, Pablo. 'Ejercitando' los cuerpos masculinos y femeninos. Aportes para una historia de la educación física escolar argentina (1880-1990). Apunts Educación Física y Deportes, n. 85, p. 82-89, jul./sept. 2006.

SCHULTZ, Jaime. Qualifying Times: points of change in U.S. Women's Sport. Illinois: University of Illinois, 2014.

TRAVERS, Anne. The sport nexus and gender injustice. Studies in Social Justice, v. 2, p 79-101, 2008.

WILLIAMS, Jean. A Beautiful Game: International Perspectives on Women's Football. Oxford: Berg, 2007. 
Resumo: Quem tem protagonizado os relatos sobre a nação? Quem tem narrado as histórias sobre o esporte, o futebol e a pátria? Que instituições foram centrais nessas construções? O que aconteceu com as mulheres? Quais têm sido os argumentos para excluírlas do campo de jogo? Estas e outras perguntas organizam o presente artigo que tem como meta refletir em torno ao esporte como prática generificada e generificadora, como um espaço de produção de desigualdades e, também, de oportunidades. Os dados que sustentam o argumento deste artigo provém da análise de entrevistas e conversas informais que tivemos com as jogadoras da Seleção Nacional de Futebol e de equipes da liga oficial da Associação de Futebol Argentino (AFA) e das notícias da edição online do jornal Olé durante a Copa do Mundo de Futebol Feminino de 2019 na França.

Palavras chave: Futebol. Nação. Mulheres.

Resumen: ¿Quiénes han protagonizado los relatos sobre la nación? ¿Quiénes han narrado las historias sobre el deporte, el fútbol y la patria? ¿Qué instituciones fueron centrales en esta construcción? ¿Qué sucedió con las mujeres? y ¿Cuáles han sido los argumentos para excluirlas del campo de juego? Estas y otras preguntas organizan el presente artículo que tiene como meta reflexionar en torno al deporte como una práctica generizada y generizante, como un espacio de producción de desigualdades, y también de oportunidades. Los datos que sostienen el argumento de este artículo provienen de los análisis de las entrevistas y charlas informales que hemos tenido con las jugadoras de la Selección Nacional de Fútbol y de equipos de la liga oficial de la Asociación de Fútbol Argentino (AFA) y de las notas de la edición online del diario Olé durante el Mundial de Fútbol Femenino 2019 en Francia.

Palabras clave: Fútbol. Nación. Mujeres. 


\section{USE LICENSE}

This article is published for open access under the Creative Commons International Attributions 4.0 (CC BY 4.0) license, which allows use, distribution, and reproduction in any medium, provided that the original work is properly cited. More information at: http://creativecommons.org/licenses/by/4.0

\section{CONFLICT OF INTERESTS}

The authors have declared that this work involves no conflict of interest.

\section{AUTHORS' CONTRIBUTIONS}

Verónica Moreira: Developed the methodological process, analysis and article writing.

Gabriela Garton: Developed the methodological process; worked on data elaboration, analysis and article writing.

\section{FUNDING}

This work received financial support from the Universidad de Buenos Aires; CONICET

\section{HOW TO CITE}

MOREIRA, Verónica; GARTON, Gabriela. Football, nation, and women in Argentina: redefining the field of power. Movimento (Porto Alegre), v.27, p. e27003, Jan./Dec. 2021. Available at: https://seer.ufrgs.br/Movimento/article/ view/109761. Accessed on [day] [abbreviated month]. [year]. DOI: https://doi. org/10.22456/1982-8918.109761

\section{EDITORIAL BOARD}

Alex Branco Fraga*, Elisandro Schultz Wittizorecki ${ }^{*}$, Ivone Job*, Mauro Myskiw*, Raquel da Silveira*, Silvana Vilodre Goellner*

*Universidade Federal do Rio Grande do Sul, Escola de Educação Física, Fisioterapia e Dança, Porto Alegre, RS, Brazil 